\title{
Mutual Obligations of Parties in Criminal Proceedings-The Context of Kosovo
}

\author{
Azem Hajdari ${ }^{1}$ \\ ${ }^{1}$ Faculty of Law, University of Pristine, Pristina, Kosovo \\ Correspondence: Dr. Azem Hajdari, Professor, Faculty of Law, University of Pristine, Pristina, Kosovo.
}

Received: December 28, 2016

Accepted: January 17, 2017 Online Published: February 20, 2017

doi:10.20849/ajsss.v2i1.113

URL: http://dx.doi.org/10.20849/ajsss.v2i1.113

\begin{abstract}
In Kosovo criminal procedure the position to be a party have the state prosecutor, defendant, and injured party. They have separate roles and clearly defined authorizations, which are linked to their procedural position. In order to achieve a fair and lawful trial, legislator gave them also several obligations which they have to fulfill to each other. Their mutual obligations mostly have to deal with the exchange of evidences, acquaintance with names of witnesses that shall be proposed to main trial, the aim of presenting an alibi etc. The importance of performing on time such obligations is diverse. This approach affects in increasing criminal-procedural efficiency, thorough resolution of a case, respect of human rights in criminal procedure etc. During the preparation of this article I have used dogmatic-legal and comparative methods as well as I have used relevant professional literature.
\end{abstract}

Keywords: prosecutor, defendant, attorney, injured party, code

\section{Introduction}

Capacity of a party is legal category. Therefore, who can be a party at criminal proceedings is determined by law. The meaning of being party in Kosovo criminal procedure has the state prosecutor, defendant and injured party. During criminal proceedings by provisions of the Criminal Procedure Code of the Republic of Kosovo several rights and obligations were entrusted to them. The main topic of this scientific paper are legal obligations having these entities to each other which are linked to criminal case for which is conducted criminal proceedings. These obligations have to deal with exchange of evidences respectively giving the possibility to take a look at, copy and photographing those evidences, acquaintance with names of witnesses, the aim of presenting the alibi, notification on purpose of filing the issue of criminal liability etc. Performing in time these obligations is very important. The importance of this issue has reflections by total and partial extension. In fact, through this approach it shall be contributed to thorough review of criminal case, it is obstructed the procrastination of criminal proceedings, it is advanced the level of communication between parties, it shall be contributed in human rights respect at criminal proceedings etc. By bearing in mind this fact legislator by law has determined specific deadlines within which parties shall fulfill their obligations to each other as well as consequences of not fulfilling them.

\section{The Meaning and Position of Parties in Criminal Proceedings}

The word a party has many meanings. For this word has been given numerous definitions. In a similar understanding with definition of a party in criminal proceedings the vocabulary of today's Albanian language determines that by the word "party is implied a person or group of persons who oppose to a person or other group of persons." (Note 1)

The capacity of a party in criminal proceedings is legal attribute. Therefore, the legislator determined by law who can have the capacity of a party in criminal proceedings. In these terms, the legislator always takes into account concrete criteria which I had considered during the determination of the word party.

Consequently, I consider in criminal-procedural terms by the word party it should be implied subject that at criminal proceeding has the legal authority to protect a particular interest. The protected interest of course should be of a personal or public (state) nature and it must have a connection with a criminal offence that is a subject of trial. It is about the subject having a key role in case resolution and has a concrete interest concerning the manner of case resolution in which he is included as a defendant or injured party, or in which he represents a general 
interest. In other words the meaning of a party at criminal proceedings may have only that subject in criminal proceedings is a holder of prosecution function (in case of injured party to initiator of prosecution) or defense. In fact, in order for a procedural subject to acquire the capacity of a party in criminal procedure he must be a holder of rights and obligations which shall be linked by a concrete criminal case. "However, in order for someone to figure as a party (state prosecutor, defendant or injured party) they must possess the so-called legitimatio ad cauzam- the capacity to figure as a criminal-procedural party in a criminal case or to be holder of rights and obligations belonging as a criminal-procedural party. When it comes to acting at criminal proceedings personally and by competence, except legitimatio ad cauzam the party also must possess legitimatio ad procedum-the capacity to undertake by itself procedural actions belonging to. (Note 2)

Kosovo legislator by solutions specified in the Criminal Procedure Code has provided equal position to criminal procedural parties. By analyzing this, with the purpose to ensure equal position of defendant to state prosecutor, legislator has guaranteed to him the right to defense, use of language, presentation of evidences, objection of prosecution evidences, silence etc.

Also, for this goal in the interest of defendant legislator has installed the institute "Reformation in peius", "Benificium cohaesionis" and "In dubio pre reo". On the other hand, legislator through legal solutions requires state prosecution impartiality in conducting prosecution function, security of relevant evidences including those which go in favor of the accused etc. Also for injured party as a party at criminal proceedings legislator has accorded concrete rights providing him equal position to two other parties at criminal proceedings. This procedural subject is entitled to provide evidences, to object presented evidences by two other parties, to seek for compensation of damage etc.

\section{Subjects in the Capacity of a Party at Criminal Proceedings}

In criminal proceedings, as above mentioned, the capacity of a party represents legal category. This capacity according to solutions set out by the Criminal Procedure Code of the Republic of Kosovo has state prosecutor, defendant and injured party. (Note 3) For their criminal-procedural position shall be discussed briefly in the continuation of this scientific paper.

\subsection{State Prosecutor}

State prosecutor is the fundamental subject and at the same time has the capacity of a party in criminal proceedings. This position dictated the legislator to determine to him state level responsibilities, but of course always balanced with the position of a party in criminal proceedings. Therefore, state prosecutor according to article 7 of the Law on State Prosecutor has the following competences and duties: a) to exercise prosecutorial functions in an independent, fair, objective and impartial manner and to ensure that all persons are treated equally before the law; b) to exercise the highest standards of care during the performance of official functions; c) to conduct himself or herself honorably and professionally in personal and professional life and pursuant to applicable law and the code of professional ethics; d) to maintain the honor and dignity of the State Prosecutor; e) to protect the legal rights of victims, witnesses, suspects, accused and convicted persons; $f$ ) to undertake the necessary legal actions for the detection of criminal offences and discovery of perpetrators, and the investigation and prosecution of criminal offences in a timely manner; g) to make decisions on the initiation, continuation or termination of criminal proceedings against persons suspected or accused of committing criminal offences; $h$ ) to file indictments and represent them before the court; i) to exercise regular and extraordinary legal remedies against court decisions; j) to cooperate with police, courts, and other institutions; $\mathrm{k}$ ) to undertake all other actions specified by law. (Note 4)

In addition to those, according to paragraph 1 of the article 49 of the Criminal Procedure Code the state prosecutor has also these basic duties and competencies: a) the state prosecutors are empowered to represent the public interest before the Courts of the Republic of Kosovo and to request the Courts to order measures in accordance with the present Code of Criminal Procedure; b) with respect to criminal offences which are prosecuted ex officio or on the motion of an injured party, the state prosecutor shall have the power to negotiate and accept a voluntary agreement with the defendant to cooperate or plead guilty. (Note 5)

\subsection{Defendant}

Defendant is a central subject at criminal proceedings to which is addressed procedural requirement, respectively is initiated and conducted the criminal procedure. (Note 6) In Criminal Procedure Code of the Republic of Kosovo has not been established any special chapter which regulates the defendant's position in criminal proceedings. However, this does not mean this issue was not handled at all by this Code. As a matter of fact 
there are numerous legal provisions included in Criminal Procedure Code, in distribution form for the defendant in many chapters.

As procedural subject the defendant has certain rights and obligations, whereas against him under conditions determined by law may be applicable also several restrictive measures. The defendant in criminal proceedings exercises the function of defense. Consequently, he is an equal party to state prosecutor. His equality to state prosecutor may be seen by the fact that for the defendant there is a presumption of innocence. (Note 7) The capacity of defendant shall be acquired by a person in the moment when against him has been filed any accusatory act, and this capacity but with terms adjusted to conducting procedure stages, he maintains until the end of criminal proceedings, meaning, up to the moment that decision on suspension of procedure, acquittal or conviction has become final. (Note 8)

In accordance to article 15 and 153 of Criminal Procedure Code, before any examination, the defendant must be informed of: a) the criminal offence with which he or she has been charged; b) the fact that he or she may request evidence to be taken in his or her defense. If the defendant is in detention on remand, he or she shall also be informed before any examination of his or her right to have defense counsel provided if he or she cannot afford to pay for legal assistance; c) the right to remain silent and not to answer any questions, except to give information about his or her identity; d) The right to be examined by the help of an interpreter; e) The defendant has the right to consult with his or her defense counsel prior to as well as during the examination.

In addition, the defendant has also these following rights: a) to object the evidences of the opposing party; $b$ ) to declare for the criminal offence he/she has been charged with; c) to examine and to propose examination of witnesses and experts; d) to appeal the court decision by a complaint and extraordinary legal remedies. In favor of the defendant have been also institutes: "Reformatio in peius", "Benificium coahesionis" and "Indubio pre reo".

\subsection{Injured Party}

Injured party in criminal proceedings shall be considered a person who has suffered any damage by the commission of a concrete criminal offence. The injured party in criminal proceedings has the capacity of a party, but which in essence changes from state prosecutor and defendant capacity, which also have the capacity of a party in criminal proceedings. The injured party has an important role in resolution of criminal case, especially to those criminal offences to which statement of injured party constitutes the sole evidence. "The injured party as a procedural subject is entitled to present the proposal for prosecution, to propose evidences, to seek for compensation of damage, to file a complaint against court decision made in the first instance for several types of criminal offences, for procedure expenditures and legal-property claim, as well as to be represented by his attorney or victim's defense counsel. Also, when the injured party is appeared in capacity of a witness, then he has all the obligations that in general witnesses have. (Note 9)

\section{Obligations of State Prosecutor to the Defendant and His Defense Counsel}

The Criminal Procedure Code of the Republic of Kosovo, except authorizations attributing his position as a state body and the basic subject of procedure, to state prosecutor also determined concrete obligations in relation to other procedural parties. In these case shall be handled with two main obligations that state prosecutor has in relation to the defendant and his defense counsel.

\subsection{Access to Case File}

In order to contribute to objectivity of trial and effectiveness of criminal process, the legislator by the article 213 of the Criminal Procedure Code of the Republic of Kosovo has determined to state prosecution that to the defendant and his defense counsel to provide access to case files. (Note 10)

The defense shall be permitted by the state prosecutor to inspect, copy or photograph any records, books, documents, photographs and other tangible objects in the possession, custody or control of the state prosecutor which are material to the preparation of the defense or are intended for use by the state prosecutor as evidence for the purposes of the main trial, as the case may be, or were obtained from or belonged to the defendant. At the initiation of the investigative stage, the state prosecutor has a positive obligation to provide access to the case file to any named defendant or their defense counsel, subject to the exceptions within this Article. At no time during the investigative stage may the defense be refused inspection of records of the examination of the defendant, material obtained from or belonging to the defendant, material concerning such investigative actions to which defense counsel has been or should have been admitted or expert analyses. (Note 11) Upon completion of the investigation, the defense shall be entitled to inspect, copy or photograph all records and physical evidence available to the court. Upon the filing of an indictment, the defendant or defendants named in the indictment may 
be provided with a copy or copies, respectively, of the case file. The state prosecutor may refuse to allow the defense to inspect, copy or photograph specific records, books, documents, photographs and other tangible objects in his or her possession, custody or control if there is a sound probability that the inspection, copying or photographing may endanger the purpose of the investigation or the lives or health of people. In such case, the defense can apply to the pre-trial judge, single trial judge or presiding trial judge to grant the inspection, copying or photocopying. The decision of the judge is final.

Despite this, legislator made clear the fact that the issue of giving the possibility to defense to inspect, copy or photograph all records and physical evidence referring to the concrete criminal case, except the fact it is linked to above mentioned restrictions dealing with endangering of investigation or the lives or health of people, this necessarily must be balanced also by measure of protecting witnesses, injured parties and their privacy, as well as by the need to protect classified information in a way that is regulated by legislation in force. (Note 12)

\subsection{Submission of Materials by Pressing Criminal Charges}

Here it is about materials which were not given to the defendant and his defense counsel during performance of investigation procedures, on the pretext that by delivering these materials it could be endangered the purpose of investigation or life and health of people. Therefore, No later than at the filing of the indictment the state prosecutor shall provide the defense counsel or lead counsel with one (1) copy of the following materials or copies thereof which are in his or her possession, control or custody, including those in the possession, control or custody of the police, if these materials have not already been given to the defense counsel during the investigation: records of statements or confessions, signed or unsigned, by the defendant; names of witnesses whom the state prosecutor intends to call to testify and any prior statements made by those witnesses; (Note 13) information identifying any persons whom the state prosecutor knows to have admissible and exculpatory evidence or information about the case and any records of statements, signed or unsigned, by such persons about the case; results of physical or mental examinations, scientific tests or experiments made in connection with the case; criminal reports and police reports; and a summary of, or reference to, tangible evidence obtained in the investigation. Giving these materials to defense counsel of course that helps the better preparation of the main trial and thorough review of criminal case. "In fact when it comes to complex criminal cases and with voluminous dossier it would be in the interest of progress of the proceedings, perhaps even its just resolution to give the possibility to defense counsel to have access in inculpatory evidence prior to completion of investigation. Consequently, I consider in these cases it would be the best to give the possibility to defense counsel to have access in evidence through submission of relevant copies. In this way to defense counsel shall be guaranteed a reasonable time, in terms of preparing better in realization of his responsibilities towards his client, but also in relation of detecting the truth concerning the case. (Note 14)

At the end it should be emphasized the fact that after the filing of the indictment, the state prosecutor shall provide the defense counsel with any new materials provided for in paragraph 1 of the present Article within ten (10) days of their receipt. However, in practice there are cases when state prosecutor, although possess an evidence estimated to have determining significance concerning the direction that shall take court decision-making regarding the concrete case, he presents that up to the end of probative procedure. In these cases to the single trial judge or the presiding judge there is nothing else left but to take over the case in terms of its administration (to accept such that evidence).

Of course that such a situation is very unpleasant for the defense and not just for it. In a situation like this it looks like there is a violation of the defendant's right guaranteed by legislation in force, because if the defense had known the fact state prosecutor possess such an evidence, it could have taken the initiative to negotiate plead guilty agreement terms, through which could take advantage of the facilities provided by the article 233 of this Code. In such cases, probably that the best possibility of defense operation is that pursuant to paragraph 1 of Article 310 of the Criminal Procedure Code which determines: in addition to cases specified in the present Code, the main trial may be adjourned under a ruling of the single trial judge or trial panel, if new evidence has to be collected, or if it is established in the course of the main trial that the accused has become afflicted by a temporary mental disorder or disability after committing the criminal offence, or if there are other impediments which prevent the successful completion of the main trial. Consequently, the defense is entitled regarding presented evidences at main trial to use also the instrument of rejection of evidence. However in order for this right to be functionalized, it is required to be discussed about evidences which constitute the violation of defendant's rights guaranteed by the Constitution. (Note 15) 


\section{Obligations of State Prosecutor to the Injured Party}

In addition to the defendant and his defense counsel the state prosecutor has concrete obligations also in relation to injured party. These obligations have to do mainly with giving the possibility to access to case files and notification for his right to require compensation of inflicted damage by the criminal offence that is a subject to judgment in criminal proceedings.

\subsection{Notification on the Fact of Being an Injured Party}

One of the obligations perhaps of initial nature of the state prosecutor in relation to injured party is undoubtedly is the one of contacting the injured party and informing without any delay about the fact that he is an injured party. This approach of the legislator has been determined by the fact that in contemporary conditions there is an extension to the maximum of situations concerning victimization of people. Bearing this in mind, some of those situations are difficult to identify, whereas some others may be identified a long time after commission of the criminal offence. This information has to deal with the respect of the injured party rights in criminal proceedings, but of course its intention is also to give him the possibility to engage in protection of his lawful rights in criminal proceedings, as well as to provide his contribution in resolution of criminal case.

\subsection{Access to Case File}

Access to case file is a fundamental right that belongs to the injured party in criminal proceedings, and at the same time an obligation which should be taken into account by the state prosecutor. Consequently, the principal solution determined by Criminal Procedure Code of the Republic of Kosovo (article 214 paragraph 1) the injured party, his or her legal representative or authorized representative, or victim advocate shall be entitled to inspect, copy or photograph records and physical evidence available to the court or to the state prosecutor if he or she has a legitimate interest. The existence of a legitimate interest of the injured party is a factual issue which must be ascertained by state prosecutor. Such may be the necessity to realize a legal- property claim. (Note 16) The court or state prosecutor may refuse to permit the inspection, copying or photocopying of records or physical evidence if the legitimate interests of the defendant or other persons override the interest of the injured party or if there is a sound probability that the inspection, copying or photocopying may endanger the purpose of the investigation or the lives or health of people or would considerably delay the proceedings or if the injured party has not yet been examined as a witness. (Note 17) Information can be redacted or marked out by a thick black line to obscure specific information by the state prosecutor on copies of documents that contain sensitive information. The provisions of the present Article are subject to the measures protecting injured parties and witnesses and their privacy and the protection of confidential information as provided for by law.

\subsection{Treatment with Respect}

The Criminal Procedure Code of the Republic of Kosovo by paragraph 1 of article 62 has established state prosecutor's obligation to treat the injured party with respect. The injured party of a crime shall be treated with respect by the police, state prosecutors, judges or other body conducting the criminal proceedings. This treatment refers to all cases and every situation, regardless of the fact which could have been its contribution in the commission of criminal offense. In this case from the state prosecutor and conducting body is required not only to treat him with dignity but also to take all the necessary measures in order to obstruct any of his outrage by any other participant in the proceedings, in order to prevent situations of re-victimization of the injured party. (Note 18)

\section{Obligations of the Defendant and His Defense Counsel to State Prosecutor}

Except above mentioned obligations which the state prosecutor has to the defendant and his defense counsel as well as to the injured party the Criminal Procedure Code of the Republic of Kosovo (paragraph 1 of article 256) has foreseen also several obligations for the defendant and his defense counsel in relation to the state prosecutor. The goal should be in function of increasing criminal procedural efficiency and more comprehensive review of evidences that would make possible to resolve fairly and lawfully the criminal case. (Note 19) For these obligations shall be discussed in the following of this scientific paper.

\subsection{Notification for the Purpose of Presenting an Alibi}

Alibi is a fact through which is noted and intended to prove the absence of the defendant at the crime scene at the time the crime is alleged to have been committed. (Note 20) Since by proving this fact depends the decision-making whether criminal proceedings shall be suspended or continue, the legislator has foreseen the obligation of the defendant and his defense counsel that to state prosecutor at the latest during the second review of indictment, to be given such a notification as far as is expectable the presentation of such a fact in criminal proceedings. (Note 21) 
Consequently, along with notification on the purpose of presenting an alibi, the defendant and his defense counsel are obliged to show to the state prosecutor the place or places where the defendant claims to have been at the time of commission of the criminal offence and the names of witnesses as well as any other evidence supporting the alibi. (Note 22)

\subsection{Notification on the Purpose of Presenting Grounds for Excluding Criminal Liability}

The perpetrator of criminal offence shall be considered liable when he possesses the ability to understand the importance of offence and the ability to control his behavior. The perpetrator of criminal offence which does not possess these two abilities or one of these two abilities in criminal law shall be considered irresponsible, respectively by mental disabilities. (Note 23) The irresponsible person can not be punished for the criminal offense committed. Consequently even though the legislator does not specify it, I consider that the defendant's attorney should notify the state prosecutor also for the purpose of presenting grounds which exclude the illegality of criminal offence (necessary defense, extreme necessity, violence, threat). Therefore, due to the effects manifesting these circumstances, the defendant's defense counsel is obliged to notify the state prosecutor at the latest until the end of the second review of the indictment for the purpose of presenting grounds which exclude criminal liability.

\subsection{Notification with the Names of Persons Intended to Be Summoned as Witnesses}

In resolution of the criminal case witnesses have often an irreplaceable role. (Note 24) This fact as well as the need to know better the personality of witness has determined the need that legislator to require from defense at the latest until the end of the second review of the indictment to notify the state prosecutor with the names of persons intended to be summoned as witnesses. Although the legislator does not emphasize it, notification has to do with clear identification of witness (his personal data) and notice of his permanent or temporary residence and other data that could be necessary. Even in this case the goal is to contribute to the efficient development of criminal procedure and thorough review of the case. "Notification given to state prosecutor on time by defense with the names of witnesses reduces the possibility of procrastinating criminal proceedings through presenting new witnesses" (Note 25) therefore the legislator rightly set time limits of performing this obligation by the defense.

\section{The Importance of Determining and Fulfilling Mutual Obligations of Parties in Criminal Proceedings}

Determining and fulfilling mutual obligations of parties in criminal proceedings is very important. Consequently, this issue manifests interest in criminal procedure law, as well as in criminal policy. (Note 26) As a matter of fact, the importance of determining and fulfilling mutual obligations of parties in criminal proceedings reflects in the following aspects:

1. Effects in increasing procedure efficacy-conducting mutual obligations of parties in criminal proceedings on time reduce the possibility of procrastinating criminal proceedings. In this way shall be eliminated the possibilities of parties to seek for a postponement of the main trial, on the pretext that they were not aware of any evidence. This approach by bearing in mind the fact in Kosovo courts and prosecutions wait for respective criminal-procedural addressing about half million court cases, of which nearly half of them are of criminal nature has a great criminal-policy importance. (Note 27)

2. Advances the protection of human rights in criminal proceedings. Conducting mutual obligations of parties in criminal proceedings reduces the possibility of human rights abuse in criminal proceedings. In this way, parties have better opportunities in order to prepare for protection of their rights in criminal proceedings, they have the possibility to file a concrete requests and to object criminal procedure bodies decisions concerning with realization of their personal and property rights. Performing consistently reciprocal obligations by parties creates opportunities for them in terms of preparing better in the exercise of legal authorizations, sufficient time for preparation of hearings etc. This approach crowns the respect of criminal procedural legislation spirit in respecting the dignity of every participant in criminal proceedings.

3. It helps in comprehensive review of case- Performing mutual obligations of parties in criminal proceedings constitute an element of the penal process in order to ensure evidential material concerning the criminal case, through which is made possible its thorough review. Therefore, it is always expectable to reach up to the conclusion of all facts characterizing the case when regarding it shall be provided all evidences. In meanwhile, concerning this issue is very important the fact of performing consistently obligations of parties among themselves. 
4. It contributes in fair resolution of the criminal case. Performing mutual obligations of parties is of a great value in the process of comprehensive case resolution, fair and lawful decision-making regarding it. In this manner is made possible a complete and correct administration of all evidences and verification of all important facts in court's decision-making. This approach creates peace between criminal-procedural parties and is a guarantee for objective decision making.

5. It motivates criminal procedural parties in terms of advancing mutual communication. Performing on time mutual obligations advances the level of cooperation and trust between parties in criminal proceedings and enables to them facilities in fulfilling their legal obligations. A correct communication constitutes a guarantee in terms of conducting a judicial process fairly, by providing parties more favorable environment for the realization of their rights. (Note 28)

\section{Conclusion}

Modest results of this scientific paper led me to these conclusions:

1. In criminal-procedural terms by the word part is implied subject which in criminal proceedings has the legal authority to defend a particular interest. Nevertheless the defended interest must be of personal character or public (state) and it must have connection with the criminal offense that is subject to judgment. It is about subject that has a key role in resolution of a case and who has a concrete interest about the manner of case resolution in which he is involved as a defendant or injured party, or in which he represents general interest. Consequently, in Kosovo criminal proceedings parties are: the state prosecutor, the defendant, and injured party.

2. The state prosecutor and defendant except having the capacity to act as a party, they at the same time have the capacity of a basic subject of criminal proceedings. This implies criminal proceedings cannot be conducted without their presence. Based on this fact, the legislator determined a number of rights and obligations to these subjects with the purpose to make possible fair resolution of the criminal case. By analyzing this, we come to the conclusion that the legislator granted those kinds of solutions which provide them equal position within criminal proceedings.

3. For the state prosecutor, defendant and the injured party the legislator has determined also several so-called mutual obligations. These obligations have to deal with the exchange of evidences, notification with the names of witnesses, notification with the goal of presenting an alibi, notification with the goal of submitting the criminal liability case, notification on the fact of being an injured party. In conducting these obligations the legislator has determined concrete deadlines as well as consequences for their non-fulfillment.

4. Conducting mutual obligation between criminal-procedural parties is very important. This importance manifests general and partial scope of interest. Consequently, through this approach is aimed to help to thorough review of the criminal case, obstructing the procrastination of criminal proceedings, respect for human rights, fair and lawful resolution of criminal case etc.

\section{References}

Albanian today's dictionary. (2002). Albania Academy of Sciences, The Institute of Linguistics and Literature, Tirana.

Begeja Skender. (2002). Criminalistics. Tirana.

Hajdari Azem. (2010). Criminal Procedure Law. Commentary, Pristina.

Hajdari Azem. (2013). Criminal Procedure Law. Special Part, Pristina.

Hajdari Azem. (2014). Criminal Procedure Law. General Part, Pristina.

Hajdari Azem. (2016, July). Conditional Release of Convicted Persons in Kosovo. International Journal of Research in Humanities and Social Studies, 3(7).

Islami Halim, Hoxha, Hoxha Artan, \& Panda Ilir. (2003). Criminal Procedure, Commentary.Tirana.

Latifi Vesel. (2012). Criminalistics. Pristina.

Law on State Prosecutor, Law No. 03/L-225).

Milutinoviq Milan. (1984). Criminal Policy. Pristina.

Pavišić Berislav, Vučković Milojko, Veić, Petar, \& Radolović Aldo. (1998). Zakon o Kaznenom Postupku, Zagreb. 
Sahiti Ejup, \& Murati Rexhep. (2013). Criminal Procedure Law. Pristina.

Sahiti Ejup, Murati Rexhep, \& Elashani Xhevdet. (2014). The Criminal Procedure Code of the Republic of Kosovo, Commentary. Pristina.

Sahiti Ejup. (1999). Argumentation at criminal proceedings. Pristina.

Salihu Ismet. (2008). Criminal Law, General Part. Pristina.

Shegani Altin. (1999). Comparative criminal law. Tirana.

T. Markus Funt. (2006). Kosovo trial skills handbook. Pristina.

The Criminal Procedure Code of Kosovo, Code No. 04/L-123.

\section{Notes}

Note 1. Albanian today's dictionary, Albania Academy of Sciences, The Institute of Linguistics and Literature, Tirana, 2002, pg. 9015.

Note 2. Sahiti Ejup, Murati Rexhep, Criminal Procedure Law, Pristina, 2013, pg. 151.

Note 3. The state prosecutor and defendant except having the capacity to act as a party, they at the same time have the capacity of a basic subject of criminal proceedings. This implies criminal proceedings cannot be conducted without their presence. In meanwhile, to the injured party, legislator did not grant such capacity. The injured party is a subject interested about the manner of criminal-process conclusion, but he does not hold any of the three basic functions of criminal procedure (prosecution, defense and judgment).

Note 4. Law on State Prosecutor, Law No. 03/L-225) entered into force on January 1, 2013. These competences in fact are foreseen also by the Criminal Procedure Code in the article 49.

Note 5. Hajdari Azem, Criminal Procedure Law, General Part, Pristina, 2014, pg. 133.

Note 6. Shegani Altin, Comparative criminal law, Tirana, 1999, pg. 89.

Note 7. Islami Halim, Hoxha, Hoxha Artan and Panda Ilir, Criminal Procedure, Commentary, Tirana, 2003, pg. 123.

Note 8. Hajdari Azem, Criminal Procedure Law, Commentary, Pristina, 2010, pg. 155.

Note 9. Hajdari Azem, Criminal Procedure Law, Special Part, Pristina, 2013, pg. 135; Pavišić Berislav, Vučković Milojko, Veić, Petar, Radolović Aldo, Zakon o Kaznenom Postupku, Zagreb, 1998, pg.47 - 48.

Note 10. Access for the suspect or defendant to case file according to paragraph 1 of article 213 of the Criminal Procedure Code of the Republic of Kosovo should be granted also by Police during initial investigative steps. This approach has to deal with collected evidences according to defendant's proposal, but as far as is not put in danger the goal of investigation or the lives or health of people. This possibility, probably is granted so the defendant could have an opportunity to offer its contribution concerning their collection.

Note 11. Hajdari Azem, The Criminal Procedure Code, Commentary,..., pg. 561 - 562.

Note 12. Ibid, pg. 564.

Note 13. Witness statements to the defendant must be submitted in a language he understands or speaks (paragraph 2 of article 244 of The Criminal Procedure Code of Kosovo).

Note 14. Hajdari Azem, Code,..., pg. $648-649$.

Note 15. Ibid, pg. $866-867$.

Note 16. Compare, Sahiti Ejup, Murati Rexhep, Elashani Xhevdet, The Criminal Procedure Code of the Republic of Kosovo, Commentary, Pristina, 2014, pg. 542.

Note 17. Hajdari Azem, Code,...,pg. 567.

Note 18. Ibid, pg. 160.

Note 19. Notification of the State Prosecutor with essential evidences of the defense (the alibi, evidences which exclude criminal liability) etc. later respectively at the main trial may cause postponement of the main trial in order to collect evidences in favor of prosecution, by means of which is violated the principle of procedural economize.

Note 20. Begeja Skender, Criminalistics, Tirana, 2002, pg. 265. 
Note 21. See more: Latifi Vesel, Criminalistics, Pristina, 2012, pg. 188.

Note 22. Hajdari Azem, Code,..., pg. 683.

Note 23. Salihu Ismet, Criminal Law, General Part, Pristina, 2008, pg. 278.

Note 24. See more: T. Markus Funt, Kosovo trial skills handbook, Pristina, 2006, pg. 94 - 96.

Note 25. Sahiti Ejup, Murati Rexhep, Elashani Xhevdet, op. cit fq. 645.

Note 26. Milutinoviq Milan, Criminal Policy, Pristina, 1984, pg. 321 - 323.

Note 27. Compare: Sahiti Ejup, argumentation at criminal proceedings, Pristina, 1999, 185 - 186.

Note 28. Compare: Hajdari Azem, Conditional Release of Convicted Persons in Kosovo, International Journal of Research in Humanities and Social Studies, Volume 3, Issue 7, July 2016, PP 32-39, fq.34.

\section{Copyrights}

Copyright for this article is retained by the author(s), with first publication rights granted to the journal.

This is an open-access article distributed under the terms and conditions of the Creative Commons Attribution license (http://creativecommons.org/licenses/by/4.0/). 